\title{
Coevolution of Capitalism and Political Representation: The Choice of Electoral Systems
}

\author{
THOMAS CUSACK Wissenschaftszentrum Berlin \\ TORBEN IVERSEN Harvard University \\ DAVID SOSKICE Duke University and Oxford University
}

\begin{abstract}
1 rotocorporatist West European countries in which economic interests were collectively organized adopted PR in the first quarter of the twentieth century, whereas liberal countries in which economic interests were not collectively organized did not. Political parties, as Marcus Kreuzer points out, choose electoral systems. So how do economic interests translate into party political incentives to adopt electoral reform? We argue that parties in protocorporatist countries were "representative" of and closely linked to economic interests. As electoral competition in single member districts increased sharply up to World War I, great difficulties resulted for the representative parties whose leaders were seen as interest committed. They could not credibly compete for votes outside their interest without leadership changes or reductions in interest influence. Proportional representation offered an obvious solution, allowing parties to target their own voters and their organized interest to continue effective influence in the legislature. In each respect, the opposite was true of liberal countries. Data on party preferences strongly confirm this model. (Kreuzer's historical criticisms are largely incorrect, as shown in detail in the online supplementary Appendix.)
\end{abstract}

$\mathbf{M}$ arcus Kreuzer's commentary on our article on economic interests and the origins of electoral systems (Cusack, Iversen, and Soskice 2007; hereinafter CIS) raises an important set of issues about the role of politics, to which this article is largely addressed. (He also questions the accuracy of our historical work in constructing a coordination index, arguing that 12 key assessments we make are incorrect. He is almost completely wrong: 11 of his 12 "corrections" lack historical basis. Indeed, he provides scant evidence using multiple incorrect citations and based in part on misunderstandings of our categories. ${ }^{1}$ We set out, at considerable length, detailed historical evidence in support of our assessments in the online supplementary Appendix, Section 1, which we hope the reader will consult, at http:// www.journals.cambridge.org/psr2010001)

In CIS, we proposed a political economic explanation of the choice of proportional representation

Thomas R. Cusack is Senior Research Fellow, Wissenschaftszentrum Berlin, Reichpietschufer 50, D-10785 Berlin-Tiergarten, Germany (tom@wz-berlin.de).

Torben Iversen is Professor, Department of Government, Harvard University, 1737 Cambridge Street, Cambridge, MA 02138 (iversen@fas.harvard.edu).

David Soskice is Research Professor, Duke University, 326 Perkins Library, Box 90204 Durham, NC 27708, and Oxford University, UK (soskice@duke.edu).

We have two major debts-to Herbert Kitschelt and Pablo Beramendi, who persuaded us to focus on politics, and to Daniel Ziblatt, who pointed us to the adoption of PR in Wurttemberg in 1904. We also want to thank Fabrice Lehoucq, Cathie Jo Martin, Nicola Lacey, Philipp Rehm, Arturas Rozenas, Kathleen Thelen, the anonymous referees of a previous version of this contribution, and APSR coeditor Gary Cox for helpful comments. We thank Carsten Nickel for excellent research assistance, and the libraries of the German Historical Institute in London and the Wissenschaftszentrum in Berlin.

${ }^{1}$ We regret that we did not have an opportunity to clarify what we see as misunderstandings on Kreuzer's part. He did not share his article with us, despite having agreed to do so when we gave him our data. The only version we have seen is therefore the published one.
(PR) by a number of (proto-corporatist) West European countries in the process of rapid industrialization and democratization in the first quarter of the twentieth century, whereas other liberal countries (largely Anglo-Saxon) remained majoritarian. Our explanation is long run and structural ${ }^{2}$ : the countries that ultimately adopted PR had had (at least as far back as the mid-19th century) political economies in which the collective organization of economic activities was important. At that stage, negotiation-based polities at the local level catered to predominantly local economic networks. In the late 19th and early 20th centuries, they reconstructed negotiation-based polities at the national level when industrialization raised economic networks and rule making to that level. This required the political integration of unions and organized business together with agrarian, artisan, and other economic interests. It was achieved through proportional representation, which was but one important component of these national negotiation-based polities. It is evident that our approach owes much to the work of Katzenstein, Lehmbruch, and Lijphart. Our argument is set out in more detail later in this article, and an extensive account of our general position, which goes beyond the choice of electoral systems, is contained in Iversen (2005) and Iversen and Soskice (2009a).

This long-run political economic argument is correctly criticized by Kreuzer for neglecting the shorterterm politics of electoral choice. Political parties and politicians choose electoral systems, and CIS indeed omits a micropolitical logic of electoral choice, one that explains preferences in terms of the career goals of politicians. We agree that short-term politics should be part of the explanation, and later sections of this article are devoted to doing just this. We summarize the key points shortly. He also argues that our model

\footnotetext{
${ }^{2}$ However, it is a fully rational choice.
} 
does not fit a new set of cases, those of a number of east European countries in the early 1920s. However, our 2007 article made it clear that we are not proposing a general theory of PR adoption. In terms of cases, we joined a historically and geographically grounded debate initiated by Rokkan (1970), and subsequently formalized by Boix (1999), on how West European industrializing countries chose to reform electoral systems when the rise of labor had made the preexisting systems no longer viable. Industrialization and democratization are key to our model; with one exception, these characterize none of Kreuzer's cases (as we show in detail in the Web Appendix, Section 3); the exception is Czechoslovakia, which our model explains.

Our perspective is, however, different than that of Rokkan. Our basic concern is with the historical evolution of capitalism and how it shaped political institutions (especially in the late 19th and early 20th centuries) in what are today's advanced economies. In these countries, the right had accepted (and had had to accept) democracy by the early 1920 s. As is well known, the political institutions put in place at or by that time remained in place in almost all cases through the twentieth century. ${ }^{3}$ From our perspective, it is these longerterm arrangements that are of interest. Our goal in this article is thus to explain, analytically and empirically, why party leaderships supported these arrangements at that stage. The concerns of Rokkan and Boix, as well as that more recently of Jonathan Rodden (2008), are different. Their work on the origins of electoral systems does not distinguish between the period-mainly pre-World War I-in which electoral reform in the PR countries was compounded with the issue of democratization and the subsequent period when it was not. As we now see it, in fact, two different academic debates have become entangled in the discussion of electoral reform in the early twentieth century. The first is the debate over the choice of electoral systems (in our view, in Lijphartian terms, the choice between negotiationbased representative versus competitive majoritarian polities), and the second, the much greater and deeply divisive issue of democratization, in which the subsequent PR adopters-less so the nonadopters-were involved up to some point in the 1900-14 period. ${ }^{4}$ Our question is why, once the complex power struggles over democratization-in which the choice of electoral system was one of a number of issues, including mass male suffrage, plural votes, redistricting, secret ballots, and responsibility of the government to the elected househad been resolved by the start of the 1920s, did legislatures or constitutional conventions adopt PR in one set of countries while majoritarian voting was maintained in the other? Our leading question is why legis-

\footnotetext{
${ }^{3}$ Austria, Germany, and Italy reverted to PR negotiation-based polities after World War II. France added a small portion of PR between 1919 and 1927, and then adopted PR under the Fourth Republic, before returning to a majoritarian runoff system in the Fifth Republic. Switches in New Zealand, Italy, and Japan occurred in the 1990s.

${ }^{4}$ Iversen and Soskice (2009b) suggest an explanation of the greater contestation of democracy in the PR adopters than in the liberal economies.
}

latures in those economies in which economic interests were rapidly becoming increasingly organized at the national level chose PR, whereas legislatures in the liberal economies in which the organization of interests were weak maintained majoritarian electoral systems.

(i) The model of political parties that we develop answers this question analytically. Quite different types of political parties developed in corporatist and liberal economies. These differences were critical to the preferences of political leaders over electoral systems. Where economic interests were well organized (the corporatist economies), national parties became closely linked to those interests and were seen as representing them in the legislature. ${ }^{5}$ However, single member district (SMD) systems with or without runoffs reached maximum electoral competitiveness in the 1910-1920 period (Caramani 2004). This implied an acute problem for the political leadership of "representative" parties. Party leaderships were chosen on the basis of expertise about and commitment to the relevant interest. Now, in this environment of heightened electoral competitiveness, they risked losing elections unless they could successfully compete for votes outside the groups to whom they were seen to be committed. In this situation, PR offered a wholly safer electoral environment, without obvious political cost (once electoral reform could no longer be used to keep the left out).

In contrast, the political leaders of the main "leadership" parties in the liberal economies in which economic interests were weak and ineffectively organized had every incentive to retain their power by remaining with majoritarian systems, just as the decisive median voters had strong economic incentives to keep them there.

(ii) Kreuzer asks empirically, "Wouldn't one expect to see interest groups in the PR adopters concerned about electoral reform and expressing that concern through political parties?" The answer in general is "no," interest groups did not need to tell parties what to do because party preferences were well aligned with the economic interests they represented. For various reasons, that was not initially the case in the southern German states in the pre-World War I period. In response to the absence of a "smoking gun" in CIS, we present new evidence from the southern German states in the late Wilhelmine Reich (Saxony, Baden, Wurttemberg). We show how the associations of exportoriented, skill-intensive business took key positions in political parties, saw the need to negotiate with unions legislatively via regional social democratic parties, and consciously pushed forward electoral reform to bring this about.

(iii) Kreuzer finally asks, "Does the empirical evidence of party preferences on electoral reform support our logic?" This is in fact a useful way to test the political implications of our argument, and we do so later in this article. Kreuzer himself draws a distinction between party preferences over the whole 1890-1920

\footnotetext{
${ }^{5}$ As we discuss later, this was also true of Catholic parties.
} 
period and the preferences parties finally hold, in effect, by the early 1920s. It is this latter set of preferences that is exactly relevant to the model we develop. Moreover, our model has a sharp set of predictions over final party preferences. Our prediction is that all parties in the PR adopters will prefer PR to FPTP, and all major parties in the non-PR adopters will prefer to maintain FPTP to PR. This contrasts directly, of course, with the predictions of Rokkan and Boix. ${ }^{6}$ As we show, our predictions are almost completely borne out.

\section{THE CIS ARGUMENT IN BRIEF}

Countries that chose proportional representation electoral systems in the early twentieth century were those societies that had historically had relatively negotiated forms of political decision making. These include Katzenstein's small states (1985), Lehmbruch and Lijphart's consociational countries (Lehmbruch 1967, Lijphart 1968), and Germany (west of the Elbe) and North and Central Italy. They are referred to as protocorporatist countries in what follows. In these societies, as Crouch's seminal Industrial Relations and European State Traditions (1993) shows, the nineteenth-century state and policy-making systems emerged out of Ständestaat traditions. They comprised densely institutionalized local and regional economies. Within these subnational communitiesrural Gemeinde, small and larger towns with their formal or informal guild structures, sometimes defined confessionally, linguistically, and/or ethnicallylocal decision making involved consensus-based negotiation and bargaining so that different group interests (except those without possessions) could be effectively represented. This allowed the solution of collective action problems, as well as the safe creation of cospecific assets within local and regional economic networks.

In these countries, a majoritarian electoral system worked adequately at the national level through much of the nineteenth century. Constituencies were represented in national politics by local notables elected by plurality and often unopposed. With economic interests generally geographically defined, these provided for their more or less proportional representation. With dominant local and regional economic networks, the national level was in any case less important in regulating economic activities.

By the end of the nineteenth century, however, industrialization, urbanization, and the growth of the working class had made this majoritarian system of national representation increasingly disproportional (Cusack, Iversen, and Soskice 2007, 387, Figure 2). At the same time, economic networks and regulatory legislation were becoming increasingly national to reflect the accelerating growth of industrialization. We draw attention to the growth of legislation and rule making

\footnotetext{
${ }^{6}$ Rodden's predictions are both more subtle and relate to the predemocracy period.
}

on vocational training and collective bargaining from the late nineteenth to the early twentieth century. Partially in parallel is the huge growth of industry associations and unions at the national level, and also the development of parties from parties of notables, weakly professionalized and lacking discipline, to mass parties, professionalized and with close relations to economic interest associations.

As regulatory politics and economic networks moved to the national level, parties in protocorporatist societies thus became increasingly professionally organized to represent these local, regional, and now sometimes national interests. They were "representative" parties of economic interests. Confessional parties were no exception: although Christian Democratic parties defended (within limits) the interests of the Church (although by no means always Rome), they were also, in the words of Manow and Van Kersbergen (2009), "negotiating communities" for the many different economic groups-handwork and the Mittelstand, small-holding peasants, larger peasants, Catholic unions, and landlords and sometimes business (see also Kalyvas 1996 and Blackbourn 1980). This reflected the fact that economic life was partially organized on confessional lines in the relevant countries.

Our theory implies that, in the protocorporatist countries in which PR was adopted, it did not signal a sharp break with previous forms of representation. Rather, industrialization threatened in two ways the continuation of consensus-based negotiation over regulatory issues in a locally and regionally rooted representative system in which majoritarianism had operated broadly proportionally. On the one hand, it pushed important regulatory issues (e.g., handwork rules, education, vocational training, collective bargaining) to the national level. On the other hand, it threatened the separate parliamentary existence or weight of the regional, confessional, and ethnic "interest carrying," as well as sometimes national liberal and conservative parties, as a result of the distorting effects of mass electorates and the complex demographic reconfigurations brought by rapid urbanization.

This ultimately led to the adoption of PR. It did not require exceptionally rational forecasting. Once the move to the national level of industry and politics made it apparent that the preexisting majoritarian institutions of representation were producing stark disproportionalities, PR was the natural choice to restore representivity. Interest-carrying parties needed to preserve their identity to be able to continue to represent their interests at the national level. The transition to PR was a means to restore a negotiation-based political system in which different economic interests were effectively represented by parties. To do this, there was no obvious alternative to PR, and because it was supported across the party spectrum (as Kreuzer's own data clearly show), its historiography is quite limited (as Kreuzer also underscores)-it was not a fundamental issue in contrast to democratization.

These reasons for the adoption of PR are closely related to a prominent perspective on PR as a consensual and inclusionary form of democracy (Katzenstein 1985, 
Lehmbruch 1967, Lijphart 1984, and Powell 2000). In this perspective, PR facilitates Pareto-improving political exchanges between groups with distinct, yet overlapping interests. The concept of cospecific assets is meant to highlight production systems where the pattern of asset ownership ties together otherwise competing interests. The obvious example, because it was so central to politics in the countries and period on which we focus, is the presence or absence of cospecific investments in human capital. However, the argument also applies to co-owned production facilities and distribution channels in the case of agricultural cooperatives, applies to wage bargaining when unions can credibly threaten to hold up production, and can be thought of in terms of Putnam's concept of social capital as horizontal interdependencies among people in social and organizational networks (Putnam, Leonardi, and Nanetti 1994).

The inclusionary logic, however, is only part of the story. It explains why policies in a range of regulatory areas are effectively decided through parliamentary committees with proportional representation and intimate ties to bureaucratic agencies, which in turn have close ties to organized groups. However, redistributive policy-the politics of distribution as opposed to the politics of regulation-is different because the great majority of PR systems have governments based on bare majority class coalitions that control decisions about taxes and spending. This logic of exclusion and minimum winning coalitions is emphasized in Korpi and Shalev (1979), Huber and Stephens (2001), and Manow and Van Kersbergen (2009). For reasons explained in Iversen and Soskice (2006), coalition governments under PR tend to be center-left and redistributive, in contrast to median voter-oriented majoritarian systems. Thus, in fiscal policy, unlike regulatory policy, the main effect of PR is to raise social spending and redistribution. It is precisely for this reason that the right would never have supported PR if their aim had been to contain the redistributive threat from the left. This is one reason that the standard model, at least in the Boix formulation, is theoretically untenable.

This redistributive logic also helps explain why the liberal cases (Great Britain, the white settler colonies, and the US) stayed with majoritarian institutions. The center and right in these countries had no reason to abandon a system that effectively excluded the poor from government and focused on the interests of the median voter. They also had no countervailing reasons to favor PR in order to cultivate coordination and consensus-based decision making. There was no Ständestaat tradition; the state was at arm's length from the economy (at least in contrast with the protocorporatist countries); there were no deep local institutions, urban or rural, and the guild system either did not seriously exist or had long fallen into disuse; and the organization of labor markets was relatively flexible. France does not fit perfectly into the liberal categoryit never had the clear distinction between state and private sector of classical liberalism (Crouch 1993) - but, in other respects, France operated as a liberal political economy, and we refer to it as liberal in the context of this debate. ${ }^{7}$

\section{HEIGHTENED ELECTORAL COMPETITION AND FIRST PAST THE POST: THE TRILEMMA OF REPRESENTATIVE PARTY LEADERS}

Kreuzer's central point is that the choice of an electoral system takes place within a legislature or a constitutional convention in which the key actors are politicians and political parties. In contrast, the key actors in CIS are economic groups, business associations or unions, and peasant and artisan organizations. A bridge is needed from the economic interest argument to the political decisions, and we construct it analytically in this section.

We show empirically in the next section that, as our theory predicts, almost all parties in the PR adopters eventually favored PR, and the major parties in the nonadopters favored the retention of majoritarianism. Why were these rational preferences for the political actors? What were the career incentives of politicians and the organizational motives of parties to push the protocorporatist countries to $\mathrm{PR}$, and to retain majoritarian electoral systems in the liberal economies?

In developing a simple rational choice model to answer these questions, we also want to explain why the choice of electoral systems appears not to have been a deeply important political issue. Blais, Dobrzynska, and Indridason (2005) argue that there were no great divisive political debates on these issues (once democratization had taken place). This doubtless accounts for the absence of a historiography of electoral choice, which Kreuzer notes. Our model of political choice argues that the choices were obvious to politicians and followed from differences in the goals and structures of parties in the two different environments.

Historically, we can largely but not completely disentangle the democracy debate from that on electoral systems. We have broadly in mind in our analytic model party preferences from the early 1920 s on in the PR adopters. In contrast, during the messy period of democratization in the first two decades of the twentieth century, the configuration of electoral systems is one among a number of balls in the complex game in which democracy is established. It is to this stage that both Rokkan and Boix, as well as Rodden, relate. Most of this stage is occupied by five issues: the extension of male suffrage; the reduction in the powers of the upper house of the legislature; the abolition of plural votes, nonsecret ballots, and property or educational qualifications; the responsibility of government to the elected house; and the winding down of gross working class disproportionalities. This latter issue was a key element of the democratization process for the basic

\footnotetext{
7 As do both Luebbert (1991), who has a similar division of countries to that here (apart from Switzerland, classified as liberal), and Kuisal (1981), who argues explicitly for a liberal interpretation of the French political economy.
} 
reason that Rodden (2008) gives: the socialists overaccumulated votes in large urban constituencies, and the conservatives benefitted from small rural constituencies. The normal preference of socialists was thus for $\mathrm{PR},{ }^{8}$ and it explains why on occasion conservatives wanted to maintain single member districts. That is, smaller liberal parties with thinly spread urban votes preferred PR (or plural votes), and Rodden is surely right here in his general analysis. There is little evidence from party preferences that that a divided right wanted PR to keep the left from power as Rokkan (1970) and Boix (1999) propose.

In contrast, our argument is about the relationship between party organization and electoral competition once reasonably democratic conditions had been met in the early 1920s. By the turn of the 20th-century, political parties in the PR adopters were closely connected, with organized interest groups representing important economic sectors of society-partly through key individuals in the associations and partly through organizational integration. Industry associations were typically linked to liberal parties, and centralized industrial unions to social democratic parties; peasant organizations and cooperative movements were variously located in agrarian parties or conservative parties; conservative parties often also incorporated the artisan sector; and so on. A variant of the interest party linkage, equally in the PR adopters, was provided by Christian Democratic parties, which were organizationally based on Catholic organizations covering different economic groups (with peasant and handwork associations of more importance and Catholic unions of less, and business relatively unimportant). ${ }^{9}$ Throughout this period in these countries, organized economic interests, acting through political parties, had a growing need for political representation in political fora where problems could be bargained out between interconnected interests and interest-bearing parties could retain their core identity.

Parties and interests developed quite differently in the liberal economies. Business associations and chambers of commerce had little power over their members. They found it difficult to coordinate political strategies geographically or across industries. Unions were primarily craft based and uncoordinated. Neither the artisan sector nor agriculture had strong organizations.

\footnotetext{
${ }^{8}$ Although PR is indeed a simple way to reduce disproportionalities, it can also be done by constituency creation and redistribution in a majoritarian system-this was how relative working class proportionality was eventually achieved in the UK (as long as the disadvantaged party is large enough. It would not have worked for liberal parties whose small urban electorate was scattered across constituencies. That is why small liberal parties demanded plural votes, often based on educational qualifications when working class suffrage was increased without a move to a PR system.) The removal of antileft disproportionalities did not require PR. So, although the choice of electoral system was not unimportant in the process of democratization, it was often a bargaining chip or a propaganda device that the parties used in the much bigger issue of democracy for lower-income groups.

9 This is one reason why effective Catholic parties did not develop in neither France nor New South Wales in the late nineteenth century, despite state attacks on Catholic education systems.
}

There were of course linkages with political parties, but these were not constraining on the parties; and party leaderships early understood the importance of focusing on the "middle" groups, whether the "respectable working man" or the lower middle class or clerical workers (the UK Conservative and the Liberal parties competing in the last third of the 19th century for just these groups).

In addition to these developments of political parties, there was a profound change in the nature of political competition. This is a major theme of Caramani's seminal book, The Nationalization of Politics: The Formation of National Electorates and Party Systems in Western Europe (Caramani 2004). Caramani emphasizes the growth in the competitiveness of SMD elections as the territorial heterogeneity of politics declined, implying inter alia "from the 1870s and 1880s until WW1... a rapid and constant increase in the share of constituencies in which parties contest elections" (Caramani 2004, 74). Likewise, in the countries with run-off systems for which he has sufficient historical data (the Netherlands, Belgium, Germany, Norway, Switzerland), this is paralleled by a similarly dramatic increase in the proportion of second round contests. Caramani shows that this rise in electoral contestation is a common phenomenon (at least across Western Europe, including Great Britain). We argue that this had quite different implications for party preferences over electoral systems for the two types of parties, representative and leadership, that we discuss.

\section{The Trilemma of Representative Parties and Their} Leaders. We make the broad assumption that party leaders in representative parties are chosen as known to be committed to the goals of the interest-frequently senior officials, perhaps lawyers, with expertise in the issues concerning the organized interest-and that that is common knowledge to voters. From the perspective of the organized interest group, the party in the legislature can then be relied on, in terms of goals and technical knowledge, to negotiate and carry relevant detailed legislation through the committee structures on which all relevant parties were represented. Finally, we assume that the party leader makes the decision about the party's choice of electoral system, so it is his or her preferences in which we are interested. We make these assumptions to underline the interest of the party leader (and leadership group), even if or when a leader cannot be recalled by the interest group.

What happens to the constraints facing a leader of a representative party when nationalization of politics increases the degree of electoral competition to the point of a large proportion of seats being closely contested, as Caramani (2004) argues was becoming generally the case in this pre-PR adoption period? The survival of a multiparty representative system may or may not be associated with run-offs, as often was the case; however, even so, major problems arise for interest-committed party leaders. For, given the degree of electoral competition and the majoritarian system, parties now need, say in a close run-off race, to be able 
to appeal to voters from other groups whose candidates have been knocked out. This implies a trilemma for the party and its leader.

\section{Either:}

I. Keep the majoritarian system, but replace the existing party leader by a new leadership with wider appeal that can compete credibly for votes outside the interest to which the existing leader is committed.

Or:

II. Keep the majoritarian system, but reduce the degree of electoral competition by some form of cooperation between the parties (electoral pacts, party mergers).

Or:

\section{Switch to PR.}

Party leaders, and the leadership group, will find the first alternative unattractive if one of the other two alternatives are available. They have themselves been selected because of their technical expertise, and their commitment to group interests is likely to preclude a wider appeal. As to the second alternative, electoral pacts (normally informal agreements between the parties about mutual stand-downs of candidates) were common in this immediate pre-PR adoption period, but they were usually unsustainable and unstable, as well as distracting in terms of party organizational resources. ${ }^{10}$ Even more problematic for party leaders is a merger with another party because the leader then has to share power and risks being displaced by the leader of the other party-not to mention the organizational costs and uncertainties involved.

The third alternative, the switch to PR, is generally attractive to representative parties and their leaders. If parties are representative of their core constituents and if the electoral system is PR, then voters have no incentives to vote for parties that do not represent them, and all parties have an incentive to target their campaign to their own group. The reason is that if a party representing a particular group campaigns for the votes of other groups, it will be in a competitive disadvantage compared to the parties that already represents these groups, and by campaigning for the vote of other groups, parties will dilute their support among their own core constituencies. Such targeted campaigning in turn has the consequence of making electoral markets highly segmented and noncompetitive.

For this reason, representative parties will normally prefer PR, and the organized interests and voters that parties represent will favor PR for the same reason. This is reinforced by the legislative payoffs to each group/party from the effective representation of the interest in such a system. A characteristic of the representative leader is that his or her objective is that of the interest, and for this to be plausible to the electorate,

\footnotetext{
$\overline{10}$ This is potentially costly to party officials when having to persuade party voters to vote for a candidate of another party of which the voter disapproved.
}

the leader and the leadership group around the representative leader will normally have had long-standing technical and organizational ties to the interest. Moreover, if the returns to one interest of legislative representation are positively related to the representation of another interest, which is the case with asset cospecificity, then we would expect each party representing a specific interest to be concerned that other interests are effectively represented in the legislature as well. When interests are specific and parties are representative, there is no conflict between groups and parties over institutional preferences. All groups/parties favor $\mathrm{PR}$, and PR in turn ensures that cospecific assets are protected and therefore makes continued investment in such assets favorable. ${ }^{11}$

The Nondilemma of Leadership Parties. Now move to the liberal world and consider the majoritarian case with leadership-based ("Downsian") parties. Because only parties that can attract voters from different groups will be represented, a majoritarian system gives a comparative advantage to broad, nontargeted campaigning. In addition, the increase in electoral competition over time that Caramani (2004) describes implies a continuing increase in the benefit of this form of campaigning. As we said previously, organized interests in these systems are weak, reflecting an economic world of nonspecific assets, so from both organizational weakness and limited concern for close legislative involvement, organized interests do not play a dominant role in these leadership parties. Instead, parties primarily represent broad class interests. Because the middle class is well represented in a majoritarian system, it has no incentive to prefer a change in the status quo. And because parties are organized to represent the middle class credibly in order to win elections, there is no effective voice advocating a shift to PR. This is reinforced by the simple fact that populist leaders would lose their position in a system with representative parties. Thus, a majoritarian system undermines the political protection of specific assets, and instead encourages investment in general assets. As this process unfolds, the support for a continuation of the majoritarian system becomes increasingly entrenched. Minority interests will always want institutional change, of course, but they will never have the legislative majority.

We can see from this analysis that a political economy that starts out with heavy investment in cospecific assets will be dominated by groups that prefer representative parties, who in turn will favor PR when politics becomes nationalized. Electoral campaigning will be targeted, and electoral markets will be segmented and noncompetitive. If we instead start out with a political economy that is characterized by heavy investment in general assets, it will be dominated by middle class interests that prefer leadership parties, who in turn will

\footnotetext{
11 Again, the exception is when groups are heavily concentrated geographically because a representative party will then also be the majority party in each locality. The nationalization of politics, and the attendant disproportionality produced by such nationalization (as described by Caramani 2004), is what causes PR to be the almost universal preference in protocorporatist countries.
} 
favor majoritarian institutions. Electoral campaigning will be nontargeted, and electoral markets will be integrated and competitive. It explains why, as Carstairs (1980) notes, the number of parties remained the same after as before. It also explains why, in each case, the characteristics of parties and their leaders made these choices noncontroversial.

\section{WHIFFS OF SMOKE: SAXONY, WURTTEMBERG, AND BADEN, 1900-1914}

Profound changes occurred in the PR adopters in the late 19 th and early 20th centuries. Three interacting and mutually reinforcing political-institutional developments were working themselves through (1) the massive growth of economic rule making and the change of its locus from the local to the national (in Germany, to both state and national); (2) the move of political parties from parties of local notables to national professional parties, and the same happening to interest organizations; and (3) the increasingly close links of these parties to interest organizations (whose leaders were often in the leadership group of the relevant party and for whom national political representation was becoming ever more important).

The basic driver of our argument is that organized economic interests sought effective expert representation in national legislatures in which the details of regulatory laws were negotiated out. Parties were in consequence representative of interests, and for the reasons set out, representative parties preferred PR as a means of safeguarding their interest identity and enabling technically expert ${ }^{12}$ party leaderships committed to the interest to remain at the helm.

Kreuzer asks, "What is our evidence for this 'basic driver' of our argument? Where is the smoking gun?" We cannot easily test this story from the postdemocratization wide acceptance of PR; as seen later in this article, all parties were agreed at that stage, precisely as we would expect, so no serious debates took place. We are therefore thrown back to the earlier and more confused immediate prewar period, where there was more disagreement about the role of parties. The German states in the late Wilhelmine period provide an as yet unexplored testbed for theory in this area. The legislatures of the German states were more important than the Reichstag as a locus of detailed economic rule making. This was because of the power of the states in the Bundesrat to block legislation at the Reich level ${ }^{13}$ thus, to be successful, Reich legislation left detailed implementation to the states, as exemplified by the 1897 Reich legislation on guild privileges (Blackbourn 1980, 156-7). The states offer opportunities for testing because of the geographic division across the German states between those in which the dominant industrial force was heavy industry and those in which light industry was more important (Herrigel 1996). Heavy industry was dominant in Prussia; light industry

\footnotetext{
12 "Fachlich" is Stresemann's term.

13 See Thelen and Karcher 2007 on the power of the states in the pre-World War I Reich.
}

(high value-added export-oriented machine builders) in Baden, Saxony, Thuringia, and Württemberg (Herrigel 1996, 116). Heavy industry (iron, steel, and mining) was organized in the Zentralverband Deutscher Industrieller (ZvDI), closely linked to the Conservative party, and hence to the East Prussian land-owning nobility and the conservative peasant organization BdL. ZvDI was hostile to the Social Democratic Party (SPD) and sought to keep unions outside the plant while providing training and a private welfare state within. ${ }^{14}$ Only as these big companies gradually expanded into the more skilled areas of machine building just before World War I and in the 1920s did they accept the need for collective bargaining and public training schemes. However, pre-World War I, heavy industry had no concern to negotiate politically with the representatives of labor; it was content with a Prussian political system that kept the SPD out through its three-class voting system while giving heavy industry close links to the government and policy making.

Light industry, however, with highly skilled workforces and limited resources to withstand long strikes accepted unions to a greater degree and believed, for example, in public training systems for industrial workers. The result was a different relationship between industry and labor in Baden, Saxony, and Württemberg, ${ }^{15}$ with state Social Democrats more flexible and pragmatic ${ }^{16}$ (and periodically in conflict with the national party), and light industry more open to the political representation of the socialists and hence the unions (Pohl 1995, Retallack 1990, Ullmann 1976, Warren 1964). Light industry was represented by the different liberal parties: the Saxon industry organization, the Verband Sachsischer Industrieller (VSI), took over the National Liberal Party (NLP) in Saxony; its sister and more radical association, the Verband Württembergischer Industrieller (VWI), was closely linked to the Fortschritt Volkspartei or left liberals (the main liberal party in the state) in Württemberg (Blackbourn 1980, 120-65), and the same is true for the Verband Badischer Industrieller later the Verband Südwestdeutschland Industrieller, (VSDI), in Baden. ${ }^{17}$

Nowhere else in Germany seems to have come as close to adopting PR, or finding a way of incorporating the SPD, as these three states. Württemberg did, Saxony nearly did and changed its rules in a related way, and Baden (with universal male suffrage and constitutional government) adopted an electoral pact system that preserved party identity.

We illustrate the point using Saxony, where most work has been done by historians on the role of regional industry in politics, perhaps in part because of the key role of the youthful director of the VSI, Gustav Stresemann. ${ }^{18}$ Saxony had a powerful labor

\footnotetext{
14 On these divisions between heavy and more export-oriented light industries in Germany, see Thelen 2004 and Herrigel 1996.

15 We have not been able to find information about Thuringia.

16 Blackbourn $(1980,123)$. In addition, unions were a more pragmatic and increasingly dominant force in the Reich SPD.

17 On all this, see Ullmann 1976.

18 Stresemann, one of the leading figures of Weimar, came into politics via business associations, having been director at age 23 years
} 
movement that had been excluded from a role in the Saxon Landtag by legislation in 1896, copying the 3-class voting system in operation in Prussia and promoted by both the Conservative party and the NLP. However, also excluded had been Saxony's light export- and skills-based industry, much at odds with the interests of heavy industry of the Reich and agriculture (the iron-rye coalition), which dominated the Conservative party in Saxony and to which the NLP, still a party of notables at the end of the 19th century, were somewhat uncomfortably attached.$^{19}$ By 1904 , both the hitherto reactionary Saxon government and the NLP, which had been partially taken over by the VSI, sharply changed tacks. According to Retallack (1990, 287), the leading American historian of "Red Saxony":

With some oversimplification one can say that the [new National Liberal] political reasoning ran remarkably parallel to that of the Saxon government. Just as the technocrats who were busy drawing up franchise reform proposals in the Saxon interior ministry believed that the representation of economic interests belonged in any blueprint for Saxony's future electoral system, important members of the Saxon NLP now recognized that political power and economic power devolved jointly toward those who could mount effective lobbies at the locus of decision-making in the state. Thus 1902 witnessed the first concrete action of a handful of Saxon businessmen, mainly in Dresden and Leipzig, who recruited Gustav Stresemann (the later National Liberal leader and Weimar statesman) to form the Association of Saxon Industrialists (Verband Sachsischer Industrieller or VSI) in order to press their special economic interests. As another symptom of these men's impatience, the Saxon wing of the NLP disavowed the national party's accommodation with Bulow and the Conservatives over tariffs in late 1902 . Within only a couple of years, Stresemann and the 4,000 businessmen organized in his new lobby exercised direct influence over the left (and younger) wing of the Saxon National Liberal Party. Concentrating every effort on disengaging the National Liberal Landtag caucus from ... the Conservatives, they tried to convince their party leaders, first, that a new system of selecting members to both houses of parliament was the conditio sine qua non for the further blossoming of industry in Saxony; and second, that a ruthlessly antilabor and anti-reform policy was no longer viable in the "red kingdom."

Five years of confused and acrimonious debate elapsed before constitutional reform occurred in 1909. By the 1907-9 Landtag, the government "agreed with the [VSI] view that industrial workers' representation must be increased in the second chamber" (Warren 1964, 77). ${ }^{20}$ The Saxon government was not formally responsible to the Landtag, but informally only made

of the Dresden Chocolate Makers Association before moving to the VSI in 1902. He was, in addition to being a brilliant organizer, an exceptional strategist and polemicist. It is for this reason that we have knowledge of the motivations of the VSI (Ullmann 1976).

19 " 61 The interests of the industrial sector were virtually unrepresented in the Landtag, ignored by the Saxon authorities" (Wright 2002, 32).

${ }^{20}$ Stresemann $(1935-40,12)$ previously proposed socialist representation in the committee system in Dresden council. major moves with the approval of both Conservatives and the NLP. It was also increasingly concerned with the development of industry in Saxony, as well as the capacity of the unions to demonstrate. After serious attempts by the government to reform the legislature with a second chamber based on election by economic interests (a Berufung system), and then by a mixture of proportional representation (45 seats) and communal members (40), the final agreement among the government, the Conservatives, and the NLP was motivated pragmatically by three considerations: the SPD should have substantial representation but not a majority in the lower house, nor should the Conservative party have an overall majority, and the NLP should be well presented. In addition, the socialists should be members of the committee system (where the details of legislation were negotiated out). These conditions were substantiated with a system of plural voting to hold back the possibility of a socialist majority, reinforced by the requirement of an absolute majority for victory (to rule out a conservative majority). In effect, the SPD then held something like an electoral balance of power because they could influence many runoffs in a liberal direction. However, the pragmatic system was also set up so that the Saxon SPD, probably the most electorally powerful in the Reich, should not get a legislative majority; hence, proportional representation was seen as dangerous by both Conservatives and the NLP. The system of plural voting and absolute majorities at the same time prevented the Conservatives from gaining an overall majority. Solving the trilemma was not a problem for the Conservatives whose interest was agriculture, heavy industry, and the protectionoriented guild sector. It was in principal a problem for the NLP, but the NLP could focus on light industry and the educated urban bourgeoisie as a result of the plural vote, and it was aided by an implicit electoral pact with the SPD, given the reformist attitude of the NLP and its openness to the SPD. (Of course, by 1918, once the power of labor ruled out plural voting and unrepresentative rural constituencies, all parties accepted PR rather than redistribution of constituencies and electoral pacts.)

This was a classic situation of representative parties. In effect, "each lobby (the Bund der Landwirte for the Conservative/agrarian party and the VSI for the NLP) controlled a party deputation.... Each lobby was not just affiliated to but aligned with a party-was by 1907 virtually a political party" (Warren 1964, 77). Equally, the SPD was closely linked to the unions.

We have not been able to find such direct evidence of the role of interest groups in influencing electoral reform in Baden or Württemberg. In both states, associations of light export-oriented industry had been set up along the same lines as the VSI. Indeed, Stresemann had played an important role in doing so, and both the VWI and the Verband Badischer Industrieller, later the VSDI, were affiliated to the Bund der Industriellen (BDI), the loosely based Reich organization of light industry close to the Reich $\mathrm{NLP}^{21}$ and politically

\footnotetext{
21 Thus, partially explaining its weakness (Martin 2009).
} 
more socially oriented than the heavy industry-based ZvDI. As Ullmann $(1976,40)$ shows, Saxony, Baden, Thuringia and Württemberg were overwhelmingly the largest state organizations in the BDI, with Prussia having only half the membership of Württemberg. The VWI, moreover, and to only a lesser extent the VSDI, (Ullmann 1976, 57 et seq), were more radical than the VSI. Also, the SPD in both states was pragmatic, if anything more so than in Saxony. ${ }^{22}$ Thus, it is no surprise that in both states major electoral reform occurred, and cooperation between liberals and SPD was cause and consequence. In Baden, the electoral reform of 1904 allowed mass male suffrage and the secret ballot; SMDs were maintained because of rural Catholic and conservative pressure; the trilemma was solved for a decade by electoral pacts between the center and conservatives, on the one hand, and liberals and the SPD, on the other (Zangerl 1977, 221); there was a longstanding Liberal-SPD coalition government from 1904 to 1913; and Baden subsequently adopted PR before Weimar Germany as a whole did. In Württemberg, the key parties were the Catholic center party, the conservative Bauernbund, the SPD, and the left liberal VP (Fortschritt Volkspartei). All parties were in favor of PR in 1897 (Blackbourn 1980, 123), despite the disproportionality favoring the rural vote and hence the center and Bauernbund. The VP position fits exactly with the trilemma. To survive in urban constituencies under majoritarianism, the VP needed to represent liberal industrialists, the educated bourgeoisie, and the anticompetitive guild system. This was an impossibly difficult position as Blackbourn (1980; 145 et seq) explains. Württemberg adopted a modified form of PR with a major electoral reform in 1904, driven by liberals and the SPD together.

The experiences of Saxony, Baden, and Württemberg contrast with those of Prussia, where heavy industry saw no need to engage in dialogue with the unions at this period, although that rapidly changed as World War I approached, and the machine makers to whom heavy industry became close through acquisitions were much more conscious of the need for understandings with the unions and, more generally, with questions of public sector training.

\section{THE DOG THAT DID NOT BARK IN THE NIGHT: ON THE MISSING HISTORIOGRAPHY AND PARTY PREFERENCES OF PR}

Our theory, based on the model of representative parties, predicts that there should be cross-party support in the protocorporatist countries for a move to PR. Specifically, it predicts that the final decisions, once democratization had taken place, would be made with broad support from both left and right of the party spectrum. Faced with electoral competition in a majoritarian world, and without advantages of disproportionality, party leaders known to be committed to their

22 The Saxon SPD was split between a pragmatic majority close to the unions and a radical left. interest will be disadvantaged in competing for votes outside their interest. Hence, representative parties and their leaders will likely prefer the identitypreserving safety of PR. In liberal economies, in contrast, without the need for a negotiation-based political system, and with leaders chosen on their ability to appeal to the median voter, the two major parties are likely to continue to support an electoral system that focused on the median voter and avoided pressures to redistribute to the poor.

Thus, we have a sharp hypothesis. Parties in PR adopters will support PR, and major parties in the liberal countries will support continued majoritarianism. Subject to the qualification that we are interested in "final" party preferences, the right-hand side of Kreuzer's Table 3-setting out the evidence he has gathered on party preferences over electoral systems for four different party groups-strongly support our predictions. Our theory says that the predicted final preference of parties in the protocorporatist countries is in support of PR ("Yes" in Kreuzer's classification), and in the liberal economies, in support of majoritarian rules (again, "Yes"). We count cases in which parties are divided or opposed ("Divided," "No") as evidence against our theory. Of the 47 entries ${ }^{23}, 39$ are "Yes." 24 Using Kreuzer's own data, the null hypothesis that parties support is randomly allocated to "Yes" or to "No"/"Divided" can be rejected at a significance level better than .0002, using the normal approximation to the binomial distribution.

However, we also traced back historically the 8 cases for which in Kreuzer's data were "No," "Divided," or "Yes/No." (What led us to question Kreuzer's classifications more broadly was a prior examination of the justification of his classification of the Belgian Liberal position. ${ }^{25}$ ) On the basis of our historical examination (including the evidence cited by Kreuzer), we find all 8 contrary classifications incorrect. This may appear surprising, but we spell out the reasons for our reclassifications, with detailed references to the historical literature in the Web Appendix, Section 2. (Kreuzer himself gives few references on which to base his classifications, and we show that some of them lead nowhere.)

If our corrections of Kreuzer's classifications are accepted, we believe that almost all entries in the PRadopting countries are either "Yes" or "No > Yes." The exception is the "Yes > No" for the British Liberal party. This is quite consistent with our argument

\footnotetext{
${ }^{23}$ We exclude the Liberals in the UK because they ended up as a small party.

${ }^{24}$ We include the entry of "Yes/No" for the Swedish left as "No." We show that this is historically incorrect.

${ }^{25}$ Kreuzer classifies the Belgian Liberals as "No > Yes," but none of the pages referenced by Kreuzer mentioned this shift. "Containing the left threat explains why the Belgian Liberals shifted their support from the double ballot to PR after 1893" (Kreuzer 2010, 377). This is referenced to Carstairs (1980, 52-54) and to Stengers (2004, 258 $60)$. Carstairs (1980, 52-54) says nothing about the Liberals shifting support from FTPT to PR. If anything, there is a suggestion in his chapter on Belgium that PR had been a long-standing position of many Liberals. Nor is there any reference to the Liberals having shifted support from FPTP to PR in Stengers $(2004,258-60)$ or elsewhere in his article.
} 
because it had ceased to be one of the major parties in the UK majoritarian system: the Conservative-Labour tandem had reduced the Liberals to minority party status. Thus, in our view, each of the 18 countries support our hypothesis, even treated in this most stringent (deterministic as opposed to probabilistic) form.

This practical uniformity of party preferences in the two systems is a plausible explanation of Kreuzer's inability "to find any historiographical debates dealing with the economic or political origins of electoral systems." The move (or not) to PR was simply not a big issue, as Blais, Dobrzynska, and Indridason (2005) show. The dog did not bark in the night. ${ }^{26}$

\section{CONCLUSION}

The basic argument of CIS (Cusack, Iversen, and Soskice 2007) is that, in the protocorporatist countries of West Europe, economic interests had long been collectively organized, originally at the level of towns and villages. Economic rule making at the national level became important in the late nineteenth and early twentieth centuries with the increasingly rapid growth of industrialization and urbanization. In parallel, economic interests (business, unions, handwork, peasantry) organized themselves increasingly at the national level, and parties-hitherto parties of notables-now became professional parties representative of these organized interests. For organized interests, national political representation and participation in detailed law making was of importance.

Based on this long-term structural argument, this article provides a short-term explanation of the adoption of PR in terms of the motivations of political leaders and their parties. As we explain, our argument relates to the "final" arrangements in the postdemocratization period of the early 1920s. The leaders of "representative" parties were strongly identified with their particular economic interests. As electoral competition in (generally) multiparty systems heightened in SMD elections with or without runoffs in the 1910-20 period (Caramani 2004), leaders were pulled in different directions. On the one hand, they risked losing elections unless they could successfully compete for votes outside the groups to whom they were seen to be committed; on the other hand, given their perceived commitment, it was difficult for them to do so credibly. The leadership trilemma was (1) a less interest-identified leadership, (2) electoral pacts or party mergers, and (3) PR. The obvious choice was therefore PR. As we show, final preferences of all parties in the PR adopters are for $\mathrm{PR}$, just as those of the major parties in the non-PR adopters are for the maintenance of FPTP.

\footnotetext{
26 “"Is there any point to which you would wish to draw my attention?" [asked Inspector Gregory, a careful detective but one, according to Holmes, 'lacking in imagination'] "To the curious incident of the dog in the night-time." "The dog did nothing in the night-time." "That is the curious incident," remarked Sherlock Holmes.' (The racehorse trainer who spiked the favorite at dead of night was the only person whom the dog guarding the horse would not be likely to bark at. From "Silver Blaze," Chapter 1 of The Memoirs of Sherlock Holmes, by Sir Arthur Conan Doyle.)
}

How would we test our theory against an alternative? We see five central empirical facts that our theory can explain:

1. Final preferences of both left and right parties in the PR adopters were in favor of PR; at least once democracy had been broadly achieved. This is the direct prediction of our model. The Rokkan and Boix predictions are quite different.

2. As Blais, Dobrzynska, and Indridason (2005) argue, the choice of electoral system was not a divisive issue either in the PR adopters (once democracy had been achieved) or in the non-PR adopters. This is also predicted by our model.

3. PR appears to be a continuation of a relatively consensual representative system, not a major break with the past. Put more sharply, our longer-term political economic argument explains why PR adoption in the early 20th century is more or less perfectly correlated with Crouch's index of Ständestaat traditions in the early 19th, century (Crouch (1993) does not discuss electoral systems in his book).

4. The choices of electoral systems remained unchanged for more than half a century. This is despite mounting evidence that PR systems produce more redistribution, and despite the right and center having nearly always had an overall majority in PR systems. This is what we would expect since a negotiation-based political system increased economic coordination (Martin and Swank 2008), reinforcing interest groups and hence representative parties.

5. Finally, as Carstairs (1980) points out, the number of parties did not increase after PR adoption, at least for a considerable period. This is what one would expect with representative parties if interests only change over decades.

Our goal is not to explain the complex interplay of moves between democratization and electoral systems in the immediate pre-World War I period as Rodden (2008) subtly does. ${ }^{27}$ We take a longer-term perspective by trying to explain the widespread agreement about PR in the PR adopters by the early 1920 s, after democratization ceased to be contentious. However, such a long-run perspective needs to be coupled with a model of the short-run politics of electoral change, and we are grateful to Kreuzer for pushing us to provide such a model. Even if all his historical claims are incorrect (bar one), he has moved the debate forward by doing so.

\section{REFERENCES}

Blackbourn, David. 1980. Class, Religion and Politics in Wilhelmine Germany: The Centre Party in Wurttemberg before 1914. New Haven, CT: Yale University Press.

Blais, Andre, Agnieszka Dobrzynska, and Indridi H. Indridason. 2005. "To Adopt or Not to Adopt Proportional Representation: The Politics of Institutional Choice." British Journal of Political Science 35 (January): 182-90.

\footnotetext{
${ }^{27}$ See also the very interesting work of Calvo (2009).
} 
Boix, Carles. 1999. "Setting the Rules of the Game: The Choice of Electoral Systems in Advanced Democracies." American Political Science Review 93 (September): 609-24.

Calvo, Ernesto. 2009. "The Competitive Road to Proportional Representation: Partisan Biases and Electoral Regime Change under Increasing Party Competition.” World Politics 61 (2): 254-95.

Caramani, Daniele. 2004. The Nationalization of Politics: The Formation of National Electorates and Party Systems in Western Europe. Cambridge: Cambridge University Press.

Carstairs, Andrew McLaren. 1980. A Short History of Electoral Systems in Western Europe. London: George Allen \& Unwin.

Crouch, Colin. 1993. Industrial Relations and European State Traditions. Oxford: Oxford University Press.

Cusack, Thomas, Torben Iversen, and David Soskice. 2007. "Economic Interests and the Origins of Electoral Systems." American Political Science Review 101 (3): 337-91.

Herrigel, Gary. 1996. Industrial Constructions: The Sources of German Industrial Power. Cambridge: Cambridge University Press.

Huber, Evelyne, and John D. Stephens. 2001. Development and Crisis of the Welfare State: Parties and Policies in Global Markets. Chicago: University of Chicago Press.

Iversen, Torben. 2005. Capitalism, Democracy and Welfare. Cambridge: Cambridge University Press.

Iversen, Torben, and David Soskice. 2006. "Electoral Institutions, Parties and the Politics of Class: Why Some Democracies Distribute More Than Others." American Political Science Review 100 (2): $165-81$.

Iversen, Torben, and David Soskice. 2009a. "Distribution and Redistribution: The Shadow of the Nineteenth Century." World Politics 61(3): 438-86.

Iversen, Torben, and David Soskice. 2009b. "Two Paths to Democracy." Harvard University. Manuscript.

Kalyvas, Stathis. 1996. The Rise of Christian Democracy in Europe. Ithaca, NY: Cornell University Press.

Katzenstein, Peter J. 1985. Small States in World Markets. Ithaca, NY: Cornell University Press.

Korpi, Walter, and Michael Shalev. 1979. "Strikes, Industrial Relations and Class Conflict.” British Journal of Sociology 30 (2): $164-87$.

Kreuzer, Marcus. 2010. "Historical Knowledge and Quantitative Analysis: The Case of the Origins of Proportional Representation." American Political Science Review 104 (2): 369-92.

Kuisal, Richard F. 1981. Capitalism and the State in Modern France: Renovation and Economic Management in the Twentieth Century. Cambridge: Cambridge University Press.

Lehmbruch, Gerhard. 1967. Proporzdemokratie. Politisches System Und Politische Kultur in Der Schweiz Und in Österreich. Tübingen: Mohr/Siebeck.

Lijphart, A. 1968. "Typologies of Democratic Systems." Comparative Political Studies 1968 (1): 3-44.

Lijphart, A. 1984. Democracies: Patterns of Majoritarian and Consensus Government in Twenty-One Countries. New Haven, CT: Yale University Press.
Luebbert, Gregory. 1991. Liberalism, Fascism or Social Democracy: Social Classes and the Political Origins of Regimes in the Interwar Period. Oxford: Oxford University Press.

Manow, Philip, and Kees Van Kersbergen, eds. 2009. Religion, Class Coalitions and Welfare State Regimes. Cambridge: Cambridge University Press.

Martin, Cathie Jo. 2009. "Gonna Party Like Its 1899: Electoral Systems and Varieties of Coordination." Presented the Annual Meeting of the American Political Science Association, Toronto, Canada.

Martin, Cathie Jo, and Duane Swank. 2008. "The Political Origins of Coordinated Capitalism: Business Organizations, Party Systems and State Structure in the Age of Innocence." American Political Science Review 102 (2): 181-98.

Pohl, Karl Heinrich. 1995. "Eine Partei Der Konservative Honoratorien Auf Dem Weg Zur Partei Der Industrie." Historische Zeitschrift, Beihefte, New Series 19: 195-215.

Powell, G. Bingham. 2000. Elections as Instruments of Democracy: Majoritan and Proportional Visions. New Haven Yale University Press.

Putnam, Robert D., R. Leonardi, and R.Y. Nanetti. 1994. Making Democracy Work: Civic Traditions in Modern Italy. Princeton: Princeton University Press.

Retallack, James. 1990. “'What Is To Be Done?' The Red Specter, Franchise Questions and the Crisis of Conservative Hegemony in Saxony, 1896-1909." Central European History 23 (4): 271312.

Rodden, Jonathan. 2008. "Why Did Western Europe Adopt Proportional Representation?" Stanford University. Manuscript.

Rokkan, Stein. 1970. Citizens, Elections, Parties: Approaches to the Comparative Study of the Processes of Development. Oslo: Universitetsforlaget.

Stengers, Jean. 2004. "Histoire De La Legislation Electorale En Belgique." Revue Belge de Philologie et d'Histoire 82 (1): $247-$ 70.

Stresemann, Gustav. 1935-40. Gustav Stresemann: His Diaries, Letters and Papers. New York: Macmillan.

Thelen, Kathleen. 2004. How Institutions Evolve: The Political Economy of Skills in Germany, Britain, the United States and Japan. New York: Cambridge University Press.

Ullmann, Hans-Peter. 1976. Der Bund Der Industriellen: Organisation, Einfluss Und Politik Klein- Und Mittelbetrieblicher Industrieller Im Deutschen Kaiserreich 1895-1914. Gottingen: Vandenhoeck \& Ruprecht.

Warren, Donald E. 1964. The Red Kingdom of Saxony: Lobbying Grounds for Gustav Stresemann, 1901-1914. The Hague: Martinus Nijhoff.

Wright, Johnathan. 2002. Gustav Stresemann: Weimar's Greatest Statesman. Oxford: Oxford University Press.

Zangerl, Carl H.E. 1977. "Courting the Catholic Vote: The Center Party in Baden 1903-1913." Central European History 10 (3): 220 40. 